\title{
The Construction of Authentic Muslim Identity among Nationally Diverse Women: The Case of an Arab Woman
}

Burcu Gokgoz-Kurt*

School of Foreign Languages, Dumlupinar University, Kutahya, Turkey

Correspond Author: Burcu Gokgoz-Kurt, E-mail: burcu.gkurt@dpu.edu.tr

\section{ARTICLE INFO}

\section{Article history}

Received: September 30, 2017

Accepted: November 24, 2017

Published: December 30, 2017

Volume: 8 Issue: 6

Advance access: December 2017

Conflicts of interest: None

Funding: None

\begin{abstract}
This paper examines religious and ethnic identity construction among nationally diverse Muslim women, and shows how Muslim women may reflect asymmetrical power relations regarding their religiousness. While Muslims are usually treated as one homogenous community by those who are not very familiar with the Muslim communities, within the Islamic world, in fact, some Muslim-majority countries may be more strongly associated with Islam than others. Drawing on data gathered through spontaneous conversations, and informal, unstructured interviews during a gathering of four Muslim women, the present study reveals how one Muslim woman belonging to the Arab world authenticates herself in the presence of non-Arab Muslims through her discourse. Several factors such as economic wealth, heritage, politics, and language seem to help her claim "genuine" membership of Islam.
\end{abstract}

Key words:

Arab,

Authentication,

Authenticity,

Discourse,

Muslims,

Religion,

Muslim Women

\section{INTRODUCTION}

Following September 11, 2001, there has been a tendency to regard nationally diverse Muslims as a non-diverse group. While there is an existing "heterogeneity between and within the Islamic communities" (Lücking \& Eliyanah, 2017, p. 2), from an outsider's perspective, Muslims are mostly treated as one homogenous community (Halliday, 2002). In the following, Modood (2003) reveals why treating Muslims as a non-heterogeneous community is quite erroneous:

Muslims are not [...] a homogenous group. Some Mus-lims are devout but apolitical; some are political but do not see their politics as being 'Islamic'. Some identify more with a nationality of origin, such as Turkish; others with the nationality of settlement and perhaps citizenship, such as French. Some prioritize fundraising for mosques, others campaign against discrimination, unemployment or Zionism. For some, Ayatollah Khomeini is a hero and Osama bin Laden an inspiration; may be said of Kemal Ataturk or Margaret Thatcher, who created a swathe of Asian millionaires in Britain, brought in Arab capital and was one of the first to call for NATO action to protect Muslims in Kosovo. The category 'Muslim', then, is as internally diverse as 'Christian' or 'Belgian' or 'middle-class ', or any other category helpful in ordering our understanding. (p. 100)
In fact, it would be quite surprising not to imagine a "variety and complexity" in the Islamic world, given the diversity brought by geography, language, national cultures, and politics (Westerlund \& Svanberg, 1999, p. vii). The diversity and dissimilarities especially between Arab and non-Arab Muslim-majority societies have been previously investigated from a socio-political (e.g. the concept of democracy), as well as social and religious perspectives, especially of women roles and equality (Rizzo, Abdel-Latif, \& Meyer, 2007; Stepan \& Robertson, 2003). While most of those studies have compared and contrasted the varying interpretations and approaches to Islamic faith practiced by Muslims who belong to different ethnic groups, their ingroup relations within the Muslim community are still not well understood. Some of the earlier studies have looked at how authentication is claimed through mocking (Chun, 2004), vernacular uses of language in crossing situations (Chun, 2001), radio talk in form of stylization (Coupland, 2001), and cinematic representations of religious authenticity (Lücking \& Eliyanah, 2017), but far too little atten- 
tion has been paid to how authentication is gained through discourse.

The present study aims at describing how this diversity is reflected through the claims of "genuine" membership among four Muslim women. The question here is, then, what kinds of criteria are used to decide who authentically represents Islam among nationally-diverse Muslim women in a multicultural society? Therefore, the purpose of this study is to investigate (a) how nationally diverse Muslim women differ in their claims of authentic membership of Islam, and (b) the ways in which they express their opinions of what makes an authentic member of Islam. I discuss those ways an Arab woman used to claim ownership of Islam to support the idea that some members of the Arab world may authenticate themselves through discourse in the existence of non-Arab Muslims. To account for that, four closely intertwined explanations are provided. First, Arabic, the language spoken by the authenticating party, provides a strong support to claim real membership due to its peculiar status in Islam. Second, religious policies of the governments may constitute a factor in how citizens claim authenticity. Third, there is a tendency to claim ownership of religion, which, in turn, brings about authentication on the part of the allegedly "genuine" member. Finally, the speakers may rest on economic wealth to position themselves within the Islamic World. Thus, the analysis shows how an Arab Muslim woman authenticates herself as the "real" representative of Islam among three other participants through these positionings.

\section{THEORETICAL FRAMEWORK}

It is true that social ties and the feelings of belonging may help create strong bonds among the nationally diverse members of a religious group. In fact, many studies investigating the role of religion in identity construction and solidarity, as well as its relation to ethnic identity, have shown a strong effect of religion on group identity (Peek, 2005). There are various reasons as to why communities construct religious identities. As summarized by Peek (2005), immigrants, for example, constitute a good example for group identity construction through religion because they may use it as a way to (a) adjust to the environment and manage feelings of alienation and confusion, (b) access to the non-spiritual offerings such as psychological, social, economic and educational benefits, (c) tolerate the ethnic and religious differences in a society by creating a feeling of membership to a certain community, and (d) reflect self-identity as a distinct individual and social member of a multicultural society, such as those living in the U.S. While forming communities and constructing identities through religion to create feelings of solidarity as a distinct group in the larger society, these communities of practice may show asymmetrical power relations through their claims of ownership and authentication, which is how speakers" "identities are discursively verified" (Bucholtz \& Hall, 2005, p. 601). According to Lücking \& Eliyanah (2017), this is due to the aforementioned "heterogeneity" among Muslims that it seems hard to unite different Islamic communities and that "the acts of identification and differentiation" lead Muslims to "hotly contested authentic- ity" (p. 2). This, then, shows that regardless of the religious identities constructed for various reasons, "authenticity" can be a factor in shaping this process among Muslims.

The term authenticity has not been intrinsically discussed within the field of sociolinguistics (Bucholtz, 2003), and thus, may be considered an implicit theory of identity. It, in fact, has its roots in essentialism as Bucholtz (2003) summarizes below:

As an ideology, essentialism rests on two assumptions: (1) that groups can be clearly delimited; and (2) that group members are more or less alike. The idea of authenticity gains its force from essentialism, for the possibility of a 'real' or 'genuine' group member relies on the belief that what differentiates 'real' members from those who only pretend to authentic membership is that the former, by virtue of biology or culture or both, possess inherent and perhaps even inalienable characteristics criterial of membership. (p. 400)

According to Coupland (2003), “Authenticity matters. It remains to be a quality of experience that we actively seek out, in most domains of life, material and social" (p. 417). Various assumptions regarding the definition of the term have been made. It has been proposed that authenticity is "the authentic status of naturally occurring data" (Coupland, 2001, p. 346), and in fact, "specific ways of speaking and patterns of discursive representation can achieve the quality of experience that we define as authentic" (Coupland, 2003, pp. 417-418). As a concept, it carries, in itself, some sort of "authorization" or "acceptance" in "some social or cultural matrix". When something is given an authentic status, it means its "identity is put beyond challenge" by a group of "recorders", "authenticators" or "monitors" in a community. To illustrate, Coupland gives the example of authorizing an original painting as authentic by getting rid of any questions about its identity, but it is, of course, not as straightforward to specify a speaker as authentic as it is to do for a painting. In fact, determining a speaker as authentic in sociolinguistics is a challenging task to achieve as Bucholtz (2004) also puts it:

contrary to the way much sociolinguistic research has proceeded, authenticity is not there to be discovered, nor even to be cleverly coaxed into range of our recording equipment; rather it's conferred by language users and their audiences, and by us, the sociolinguists who study them. (p. 408)

Within a speech community, the actual speakers, together with their peculiar positions therein, help create the image of the authentic speaker (Coupland, 2001, p. 346). In fact, here, "the subject is both the agent and the patient of social action" (Bucholtz \& Hall, 2004, p. 382). Therefore, multiple factors -observable or discreet- come into play when describing and giving something or someone the attribute of "authentic" in empirical research. Lévi-Strauss (1976) sees authenticity as an aspired attribute in life, and considers "context" (social, cultural or stylistic) to be crucial in claiming authenticity. Depending on the interactional or sociocultural context, speakers may take on shifting identities (Bucholtz, 2003). This is not surprising given the recent move of terminology from a "static" to a more "dynamic" view in the 
interpretation of social identity and authenticity. Language is no longer seen as an intact "behavior", but rather considered "social meanings enacted in discourse, [and] locally negotiated in reflexive and strategic communicative practice" (Coupland, 2003, p. 427). So, it is not possible to determine authenticity without considering all the perplexing factors of context, speakers as well as the observer.

Bucholtz (2003) further suggests a relocation of this term and embraces the term authentication. According to her, there is a need to separate "authenticity as an ideology from authentication as a social practice" (p. 410). While authentication considers identity "the outcome of constantly negotiated social practices", in authenticity "identity is primordial" (p. 408). In fact, this view of authentication is based on the notion of tactics of intersubjectivity, which help recognize and form identities of the self and the other, using various cues such as language or other "symbolic practices". (Bucholtz, 2003, p. 408). Understanding the tactics of intersubjectivity model is crucial in the interpretation of authentication. The model refers to relations achieving their social goals in a negotiated way to form identity. Bucholtz (2003, p. 408) explains this model as follows: "identity formation is closely tailored to its context: identities emerge from temporary and mutable interactional conditions, in negotiation and often contestation with other social actors and in relation to larger and often unyielding structures of power." She further categorizes these tactics into three polarized pairings. These are adequation vs. distinction, authorization vs. illegitimation, and authentication vs. denaturalization. The polarization in this model makes it possible for speakers to position themselves flexibly anywhere on the "relational continuum" of authentication-denaturalization in their changing contexts (ibid.).

In the light of the definitions, Bucholtz (2003) concludes that, sociolinguists should talk about the "effects of authenticity" rather than "authenticity", since the former is already achieved through authenticating the practices of people who also perform and assess the language (p. 408). To put it differently, authentication occurs when a speaker claims "real" membership status within a community. And thus, the speakers' ability to "index their ethnic and nationalist stances through language choice" ultimately causes everyday speech to express authenticated language use (ibid.). The present study aims to shed new light upon how authentication is achieved through discourse by a Muslim woman in a spontaneous, everyday speech context. The analysis of the data also makes it possible to make claims about the underlying reasons for asymmetrical power relations across nationally-diverse communities in the Islamic world.

\section{METHOD}

The qualitative data presented in this paper were gathered through recorded conversations and unstructured interviews. The participants were four Muslim women: a Bangladeshi, a Libyan and two Turkish women (one of which is the researcher). The nationalities of the participants were chosen based on national diversity in order to have at least three Muslim women from distinct geographical, linguistic, and political backgrounds. ${ }^{1}$ Their ages ranged from 27-34 years, and they all lived in close neighborhoods of a middle-sized city in the southeastern United States. They came together at an apartment hosted by a Turkish woman (henceforth, Turkish woman 1; not the researcher). The interactions took place in English, in an affective atmosphere. It is difficult to know whether the "observer's paradox" operated (Labov, 1972); however, all three participants seemed to be as comfortable before and after the recording was initiated. As Johnstone (2000) puts it, sociolinguists aim to study "relatively 'naturalistic' discourse that is as close as possible to what it would have been like if it was not being taped [as sociolinguists are more interested in] tapes of 'everyday' and 'ordinary' conversation" (p. 105). This is because such naturalistic data provide the researcher with an abundance of details which paves the way for a cogent analysis and discussion of the research question. However, it would be unethical and unacceptable to collect such data in a social gathering, so the participants were previously informed about the fact that the conversations would be recorded. Still, data collection took place in and a natural conversational ambience as described by John-stone (2000).

There were mainly two concerning factors during data collection: (1) Not all four participants equally knew each other, and (2) the only common language among them was English. These factors could possibly have caused them to shy away from having a flowing conversation. Therefore, upon receiving their informed consent, in an attempt to make each interviewee feel as comfortable as possible, the researcher did not start recording until the conversation seemed to be flowing. The conversation was not initiated by the researcher, but guided by her only twice through questions to avoid too much digression. Other than those, the conversation was mostly guided by the speakers with no interference from the researcher. In addition, following the conversation at the table, partici-pants were also interviewed in an unstructured, conversa-tional manner about their view of themselves within the Islamic world.

The recorded conversations were transcribed, and for the purposes of the current analysis, no fine-grained transcription was employed. Several speech features such as pauses, interrupted speech, raised intonation, nonverbal comments and incomplete L2 English use were marked to make the analysis easier. It is of utmost importance that the findings should not be generalized to the entire Muslim or Arab population, yet the analyses offer illuminating insights into perceptions of ownership in Islam among Arab and non-Arab members of the Islamic faith.

\section{RESULTS AND DISCUSSION}

In order to explain how authentication is claimed through discourse, I mainly dwell upon the utterances of the participants, and provide four related explanations which will be discussed in the following sections. Two of these are focal and related to the language of the Qur'an, Arabic, and the religious policies of the governments; the others are rather 
peripheral explanations related to the claims of ownership in Islam and the economic wealth of the countries participants originally come from.

\section{The Arabic Language}

It seems reasonable that the Arabic language holds a peculiar status in Islam as the holy book Qur'an was written originally in Arabic. While Arabic-speaking Muslims can read and understand the Qur'an, non-Arabic speaking Muslims are not usually able to understand the content even if they may have learnt how to read the transcription. Therefore, being a native speaker of Arabic may be a factor in claiming an authentic status in Islam. This is readily observable in the following conversation between Turkish woman 1 (Turkish W1) and the Libyan woman (Libyan W):

Libyan W: I think when I came here, I became more religious here; you know why because you have nobody to talk with, and you have more time to pray and have more time to read the Qur'an.

Turkish W1: I am not like that, I was more religious in my own country because I was going to meetings for [read-ing] the Qur'an, and see other people.

Libyan W: Maybe, because your language isn't Ara-bic so you do not have - you wanna go and learn because Arabic is my language and I don't learn about the Qur'an because I already know about [it]. Yeah, so you find yourself just praying, and sometimes you just read the Qur'an, and spend the rest of the day with friends. I find more time to read more Qur'an.

Arabic is both the formal language of Libya and the language of the Qur'an. It is true that the Qur'an can be read in Arabic, in its original form, but also in its Turkish or Bengali translations. ${ }^{2}$ Here, Libyan woman may be disregarding the fact that translations offer an option to understand the Qur'an. According to the conversation, it seems that while Turkish women usually need some other people, who are more knowledgeable, to interpret the Qur'an for them, Libyan women do not seem to need anyone else probably because they already understand what is written in the Qur'an. This legitimates Libyan woman's indexing herself as being more powerful in her authenticity claims than the rest of the members at the table. There are several intertwined reasons accounted for that.

To begin with, Muslims believe that the Qur'an is the direct speech of God "revealed in Arabic to the Prophet Muhammad" (Mohammed, 2005). It is the "liturgical language in all the Muslim countries", and especially "the devout and the religious leaders" are mostly supposed to know and "recite" the Qur'an in Arabic. Also, Muslims are "required" to pray in Arabic regardless of their mother tongue (Chejne, 1969, pp. 3-9).

Additionally, in early times, the entrance of foreign words in the scripts of the Qur'an, and even the translations were not approved because Arabic was regarded essential to the Qur'an. No "foreignism" was tolerable lest it would change a small detail in its meaning, and was considered a "charge" against God. There have been discussions about the uniqueness and "superiority" of Arabic among all other languages (see Chejne, 1969, pp. 3-6). In the following excerpt, Chejne
(1969) summarizes how these approaches to Arabic were reflected later in the way the Arab world sees Arabic:

Muslims in general and Arabs in particular have long re-garded Arabic as a God-given language, unique in beauty and majesty, and the most eloquent of all languages for ex-pressing thought and emotions. Such beliefs have prevailed up to the present time, particularly in the Arab world where the pietists and nationalists consider Arabic the mainstay of the faith, the pillar of nationalism, and the differentiating factors among people who otherwise have much in common. (p. 9)

Given the orthodoxy of Arabic essentialism in the Qur'an since earlier times, it is quite explicable why being able to read and understand Arabic paves the way for people to claim an authentic status in a religious community. In fact, the last two lines of the excerpt above clearly provides an explanation as to why Libyan woman's act of authentication is fairly an expected move.

This is also in line with the following quote by Coupland (2003) in explaining how Arabic has been a means of authentication: "Authentic things, we might say, are authenticating for people who recognise their authenticity, as well as in themselves being socially authenticated" (p. 419). Here, Arabic seems to be the source of "authenticating" for the Libyan woman as she "recognizes" its authenticity, by also being "socially authenticated."

\section{Religious Policies by Muslim countries}

Being able to speak the Arabic language functions as a powerful tool in Libyan woman's indexing herself as a "true" representative of Islam compared to those who do not speak Arabic. As a response to the Turkish women's self-expression of belongingness and valuing Islamic practices, Libyan woman wants to reinforce her real membership in her further utterances upon a similar question enquiring about Libyan women's religious practices:

Turkish W 1: Don't you go and attend some kind of gathering and negotiate with your friends about Islam? Libyan W: Where?

Turkish W 1: In your own country.

Libyan W: No, because we already know about. (Audience laughter). We watch TV; we have the satellite; we have channels about Islam, and it's in Arabic. Sometimes they read the Qur'an, and they explain it to you, and [tell] stories or whatever it is about, and we understand it if we wanna learn about Islam, we just go to the TV. We have a lot of channels about Islam... in Arabic...

This time, while the Turkish W1 seems to be surprised that Libyan women do not come together with their friends to read and discuss the parts of the Qur'an, the Libyan woman expresses that there is no such need for them. This time, she seems to assure her self-essentialism through the convenience of Islamic TV channels. This is noteworthy for understanding the religious policies in Libya. Libya is a Muslim-majority country where Islam is practiced extensively, so it is not surprising that there are TV channels which offer religion-oriented programs. There may be such channels in 
all Muslim-majority countries, but the popularity and the number of them may depend on a variety of factors mostly related with the socio-political and historical background of these countries. The Libyan woman sees such channels as a reliable source to learn about Islam. Furthermore, a lack of thereof is seen as a probable reason for not being able to learn enough about Islam. This is further manifested in the following part of the same conversation about the channels: Turkish W1: We have maybe a couple of them, only a couple.

Libyan W: Maybe, this is the problem. They should make channels, Islamic channels in your language to learn more about Islam.

It is clear that the religious policies are highly regarded in informing its citizens about Islam. If a Muslim country cannot provide its citizens with such channels, those citizens may not be well-informed about Islam, and thus cannot learn enough about their religion. According to her, the need to gather to get informed about and discuss the contents of the Qur'an seems to constitute a problem, which may be originally caused by lack of informative religious policies in non-Arabic speaking Muslim countries. In the conversation, through suggestions for amendments in the religious policies of the Turkish government, the idea of true membership in the religious community is once more gauged by the established stance of governmental bodies in religious issues. In other words, according to the Libyan woman, the government's "increased care and attention to religion" in Libya leads her to self-assert herself as more powerful in claiming authenticity.

In fact, the discussion on TV channels in the conversation excerpts is just a tip of an iceberg leading to a deeper discussion especially of national and political approaches to religion and religious practices, and perhaps the government's direct and indirect involvement in this process. Clearly, Turkey and Libya are countries with different historical, socio-political and cultural backgrounds, and thus, they may not approach religion and religious practices in the same way, especially due to having quite different legislative and judicial systems. Since these differences are already known to the Libyan woman, she is mainly pointing out to the fact that citizens of those countries which are not ruled under Islamic jurisprudence may not claim as much authenticity as those who are ruled by the law of Qur'an. However, it should be noted that attitudes on the execution of such jurisprudence leading to claims of authenticity may vary among individuals, regional politics and time periods (see Power, 2015).

\section{Feeling of Ownership and Economic Wealth}

It should be noted that the Prophet Mohammed was born in the geography which is now inhabited by the Arab nations, and the religion was first introduced to the Arab world in the same region, which now constitutes the historical and religious locations of prominence for the Muslims (Rogerson, 2010). These facts, not surprisingly, have brought together a sense of ownership of Islam by Arab nations. Since Libya is considered to belong to the Arab world, the Libyan woman might intrinsically be authorizing herself in a group of non-Arab Muslim women. Inferences to prove that vary, and can be observed to varying degrees in all the previous conversation excerpts presented. This feeling of ownership seems to be affecting her discourse in talking about religion and religious practices. During the talk, at a point where negative interpretations of Islam were being discussed, she seemed to be more austere and zesty than anyone else at the table:

I was so: ma: $\mathrm{d}$ when I heard something like that.

I told her we have to do: something that's not ri: ght

this is [not Islam]

While this way of talking may be a simple way of self-expression peculiar to her personality, it may very well be an indication of ownership of religion more than any other Muslim women at the table. If the latter explanation is adopted, it seems like, being an authentic member of the religion leads her to express her feelings in a very strong way when faced with a destructive image of Islam. Maybe that is why, she feels the need to express her anger in the strongest way against those who create bad images of Islam in the media.

A corollary to aforementioned explanation is, in fact, again related with the same feeling of ownership. This time, it is about the role economic power might play in the authentication of religious identity. Libya is a quite rich, oil-based country compared to most other non-Arab Muslim-majority countries such as Bangladesh, Afghanistan or Turkey. According to the Libyan woman, in the Western media, not all but most of those non-Arab Muslim communities are usually presented as deprived of money, food or education, which may or may not be true for the majority of those nations, and this is seen in the following excerpt:

They think that Muslim people are uneducated; they don't go to school, they are poor... because the media, the media, media, showing bad things only.

It is true that the representation of Islam and Muslim nations in the Western media has been mostly derogatory in the last couple of decades. However, it is also true that, especially outside the Arab world, there are Muslim-majority countries which can be considered in poor economic condition looking at the income figures. On the other hand, in her case, she seems to be desiring to distance herself from those Muslim countries probably because in her opinion, those are not "authentic" countries to represent Islam. In this respect, through indexing herself as a member of a wealthy, educated nation, Libyan woman expresses that the only Muslims are not Iraqis, Bangladeshis or Afghans, who are usually represented as poor and uneducated in the Western media.

\section{CONCLUSION}

In this paper, I discussed how authentication was performed through discourse by a Libyan woman in a group of nationally diverse Muslim women. The data supported that she authenticated herself in four different ways. These are the language of the Qur'an, differences in countries' religious policies, the feeling of ownership due to heritage, and be- 
longing to a wealthy country. These interacting factors seemed to lead the Libyan woman to act differently with respect to her use of the tactics of intersubjectivity.

What the study reveals is interesting, because it displays how nationally diverse Muslim women reflect their positionings in Islamic community, and what kinds of criteria are at work in deciding who authentically represents Islam within a group of nationally distinct Muslim women. It seems that power relations, political and economic factors greatly affect how Muslims view and create their in-group communications within their communities of practice. It is interesting to see that while the mainstream Western media is usually representing Muslim communities in a homogenous way, Muslims desire to draw apart within the larger community of Islam to distinguish themselves from the negatively represented portion of the Islamic world. However, the findings of the study should be approached with caution because the number of participants is limited, and thus it is hard to generalize these findings to larger communities that those participants belong to due to individual differences. Moreover, construction of Muslim identities may be influenced by a variety of other subtle factors as specific as "neighborhood connections" or "class" besides those more general aspects such as global and national politics (Hopkins, Kwan \& Aitchison, 2007, p. 2). Indeed, Muslim identities and perception of Islam may greatly vary as Islam may mean different things to different people, and thus be shaped by various other personal factors (see Maloul, 2017, p. 5).

On the part of the professionals, the cross-cultural use of language to authenticate the self will bring about new perspectives in explaining the reasons for the application of binary roles of the tactics of intersubjectivity across nations within the same community of Islam. Similar studies can also be conducted to question the existence of Muslims' varying in-group indexing of the self. It can also be interesting to study the cross-cultural communication among Muslim women of various nations in relation to the notion of ownership of Islam. A better understanding of such in-group relations will also bring about a better communication as well as a mutual understanding among nations of all religions in the international arena.

\section{ACKNOWLEDGEMENTS}

I would like to thank Dr. Elaine Chun for inspiring me to work on this project.

\section{END NOTES}

1. As for their networks, the two Turkish women knew each other prior to the study. The host (Turkish Woman 1) already knew all three women, but the others met for the first time for the purposes of the study.

2. To exemplify, on special occasions such as funerals or religious days, people recite or usually invite a prayer leader to recite the Qur'an in Arabic. Besides, somebody may read the Qur'an in Arabic script, but it does not necessarily mean that they understand it. In fact, this is the case with a majority of Muslim population in Turkey excluding religious lead- ers and people who studied religion in particular. However, it should be noted that when the Qur'an is read in Arabic, it is more appreciated by the general Muslim communities in Turkey.

\section{REFERENCES}

Bucholtz, M. (2003). Sociolinguistic nostalgia and the authentication of identity. Journal of Sociolinguistics 7, 398-416. http://escholarship.org/uc/item/0sz2z8fc

Bucholtz, M., \& Hall, K. (2004). Language and identity. In Alessandro Duranti (Ed.), A companion to linguistic anthropology (pp. 369-394). Oxford: Blackwell.

Bucholtz, M., \& Hall, K. (2005). Identity and Interaction: a Sociocultural Linguistic approach. Discourse Studies 7, 585-614.

Chejne, A. G. (1969). The Arabic language: Its role in history. Chicago: U of Minnesota Press.

Chun, E. W. (2004). Ideologies of legitimate mockery: Margaret Cho's revoicings of Mock Asian. Pragmatics, 14, 263-289. https://doi.org/10.1075/prag.14.2-3.10chu

Chun, E. W. (2001). The construction of white, black, and Korean American identities through African American Vernacular English, Journal of Linguistic Anthropology, 11, 52-64. https://doi.org/10.1525/jlin.2001.11.1.52

Coupland, N. (2001). Dialect stylization in radio talk. Language in Society, 30(3), 345-375.

Coupland, N. (2003). Linguistics Authenticities. Journal of Sociolinguistics, 7(3), 417-431. https://doi. org/10.1111/1467-9481.00233

Halliday, F. (2002). Two hours that shook the world: September, 11, 2001: Causes and Consequences, London: Saqi Books.

Hopkins, P. E., Kwan, M.-P., Aitchison, C. C. (2007). Introduction: Geographies of Muslim Identities. In C. C. Aitchison, P. Hopkins, \& M.-P. Kwan (Eds.), Geographies of Muslim Identities: Diaspora, Gender and Belonging (pp. 1-9). Aldershot: Ashgate.

Johnstone, B. (2000). Qualitative Methods in Sociolinguistics. Oxford UP: Oxford.

Labov, W. (1972). Sociolinguistic patterns (No. 4). University of Pennsylvania Press.

Lévi-Strauss, C. (1976). Structural Anthropology. Vol 2. New York: Basic Books.

Lücking, M., \& Eliyanah, E. (2017). Images of Authentic Muslim Selves: Gendered Moralities and Constructions of Arab Others in Contemporary Indonesia. Social Sciences, 6(3), 103-123.

Maloul, L. F. (2017). Political Islam, Islam as faith and modernity in 1970s Egypt: a socio-political reading of Ahdaf Soueif's In the Eye of the Sun. Contemporary Levant, 1-12. Advance online publication. http://dx.doi.org $/ 10.1080 / 20581831.2017 .1365448$

Modood, T. (2003). Muslims and the politics of difference, Political Quarterly, 71 (1), 100-115.

Mohammed, K. (2005). Assessing English Translations of the Qur'an. Middle East Quarterly 12, 59-72. http:// www.meforum.org/717/assessing-english-translations-of-the-quran 
Peek, L. (2005). Becoming Muslim: The development of a religious identity. Sociology of religion, 66(3), 215-242. https://doi.org/10.2307/4153097

Power, C. (2015, March). Muslim Women are Fighting to Redefine Islam as a Religion of Equity. Time. Retrieved from http://time.com/3751243/muslim-women-redefine-islam-feminism

Rizzo, H., Abdel-Latif, A. H., \& Meyer, K. (2007). The relationship between gender equality and democracy: A comparison of Arab versus non-Arab Muslim societies. Sociology, 41(6), 1151-1170. https://doi. org/10.1177/0038038507082320

Rogerson, B. (2010). The prophet Muhammad: a biography. Hachette: UK.

Stepan, A. C., \& Robertson, G. B. (2003). An" Arab" more than a" Muslim" democracy gap. Journal of Democracy, 14(3), 30-44.

Westerlund, D., \& Svanberg, I. (Eds.). (1999). Islam outside the Arab world. Psychology Press. 